\title{
The Application of Ordered Binary Comparison and Multilevel Quantization in Multimedia Teaching Evaluation
}

\author{
Xiaoqin Xu \\ Modern Educational Technology Center of Wuhan University of Technology, Wuhan, Hubei Province, China
}

Keywords: Multimedia Teaching; Ordered Binary Comparison; Multilevel Quantification.

\begin{abstract}
Multimedia technique is a modern teaching method widely used in various universities. Objectively evaluating the performance of multimedia technique is of great significance for the management and evaluation of multimedia teaching in colleges and universities. On the basis of statistical investigation and quantitative data, this paper uses the method of ordered binary comparison to calculate weight coefficients, adopts the relative quantitative weight coefficients of 21 levels, and explores core method and grade parameter method to accurate process the results. It offers a multimedia technology evaluation model, and provides an effective approach for the evaluation and management of modern education technology.
\end{abstract}

\section{Introduction}

Thanks to the rapid development of information science and technology, modern educational technology is now developing towards the direction of intelligence, multimedia and network. As a kind of modern teaching method, multimedia technique is widely used and warmly welcomed by teachers and students. It promotes the reform of teaching content, teaching methods and teaching means. It greatly enriches teaching content, increases the approaches of information transmission, stimulates students' enthusiasm to study, and expands students' visions. Multimedia employ two or more than two kinds of media forms to disseminate information; common media forms include text, image, graphics, animation, audio and video. Various media have different forms, but they integrate with each other and serve the single goal. Today, many primary and secondary school teachers, as well as college teachers, are concentrating on making high-quality multimedia courseware. They hope to improve teaching quality and achieve desired teaching results through making high-quality courseware.

Multimedia teaching has many advantages, such as convenient, fast and time-saving. It represents clear and neat teaching contents, and saves the time of blackboard-writing. For graphics which deal with complex space relations and space structure, multimedia teaching has irreplaceable merits. Courseware with high production level and first-class animation has strong expressiveness, good controllability and strong reproducibility; they can impress and be enjoyed by viewers. Excellent multimedia courseware depends on many factors, such as teachers' making process, screen factors, visual factors, audio and sound effects, computer hardware configuration, receiving devices, beneficiaries and screen position relations, etc. These factors are integrated with each other. The relationship among them, or how to evaluate the effects of multimedia, is an issue which should be considered by teachers and students. Evaluating the effects of multimedia teaching scientifically, objectively and effectively is very necessary and important. This paper tries to discuss this issue by using the fuzzy ordered binary comparison method and the multilevel quantitative method from the perspective of teaching practice. It is of practical significance to popularize multimedia teaching to a wider range, and to further improve the quality of multimedia teaching. 


\section{Main Evaluation Indexes of Multimedia Teaching}

\subsection{Multimedia courseware.}

The evaluation of multimedia courseware started relatively late in China. In 1986, China Education Software Review Committee was set up to evaluate multimedia courseware. In the middle of 1980s, multimedia teaching appeared in China. The main popularize methods were selection and completion of courseware. In 1990s, multimedia teaching approach was widely used. However in China, the evaluation of multimedia courseware quality was usually simple and abstract, and was mainly based on the teaching attributes of courseware. In the Tenth Annual Computer Aided Education Academic Conference, scholars discussed the evaluation of multimedia courseware, put forward that the evaluation of multimedia teaching should accord with actual situations, and be more practical. It was a major improvement in multimedia teaching evaluation.

\subsection{Visual perception in multimedia teaching.}

Visual process is crucial in multimedia teaching process. Seeing with eyes is a process of encoding. Different nerve cells in retina have their respective functions; different cells stimulate and reaction to information with different characteristics respectively like a computer system, and then encode the information. The encoding process is the identification of image. Therefore, multimedia teaching should make use of the features of information and human vision. The horizontal movement of human eyes is faster than vertical movement; long time vertical movement is more easily to bring fatigue. The size and proportion on horizontal level are more accurate than those in vertical direction. In horizontal direction, the efficiency is high, and the error is small. Eyes are used to move from left to the right, from upper parts to lower parts. We see circles clockwise, and we rank these four quadrants from superior to inferior: the upper left, the upper right, the lower left, the lower right. These features should be considered in multimedia layout. The recognition of target in the best range of vision is rapid and accurate, and it is not easy to cause visual fatigue. The following Table 1 and Table 2 are used to illustrate above visual effects.

On the basis a large number of surveys and measurements on all kinds of classrooms in our school, as well as corresponding statistical analysis, data are obtained and shown in Table 1 and Table 2 .

Table 1 is the attributes of all kinds of classrooms.

Table 2 shows the distances from the screen to viewers, the left and right deflection angles, as well as the elevation and depression angles.

Table 1. The attributes of different kinds of classrooms

\begin{tabular}{|l|c|l|l|l|l|l|l|l|}
\hline $\begin{array}{l}\text { The size } \\
\text { of } \\
\text { classroo } \\
\mathrm{m}\end{array}$ & $\begin{array}{l}\text { The } \\
\text { numbe } \\
\text { r of } \\
\text { seats }\end{array}$ & $\begin{array}{l}\text { The } \\
\text { size } \\
\text { scree } \\
\text { n } \\
\text { (mete } \\
\text { r) }\end{array}$ & $\begin{array}{l}\text { The height } \\
\text { from screen } \\
\text { bottom line } \\
\text { to the } \\
\text { ground } \\
\text { (meter) }\end{array}$ & $\begin{array}{l}\text { The } \\
\text { distance } \\
\text { between } \\
\text { left seats to } \\
\text { the left side } \\
\text { of screen } \\
\text { (meter) }\end{array}$ & $\begin{array}{l}\text { The distance } \\
\text { between } \\
\text { right seats to } \\
\text { the right side } \\
\text { of screen } \\
\text { (meter) }\end{array}$ & $\begin{array}{l}\text { The } \\
\text { minimu } \\
\text { mistance } \\
\text { distween } \\
\text { between } \\
\text { seats and } \\
\text { the } \\
\text { screen } \\
\text { (meter) }\end{array}$ & $\begin{array}{l}\text { The } \\
\text { maximum } \\
\text { distance } \\
\text { between } \\
\text { seats and } \\
\text { the screen } \\
\text { (meter) }\end{array}$ & $\begin{array}{l}\text { The number } \\
\text { of stairs/ the } \\
\text { height of } \\
\text { each stair } \\
\text { (centimeter) }\end{array}$ \\
\hline $\begin{array}{l}\text { Extra- } \\
\text { large }\end{array}$ & 335 & $4 \times 3$ & 0.5 & 7 & 3 & 3.5 & 20 & $6 / 20$ \\
\hline Large & 228 & $3 \times 2.2$ & 0.5 & 8 & 5 & 4 & 18 & $5 / 15$ \\
\hline medium & 104 & $2 \times 1.5$ & 1 & 4.5 & 1.5 & 2 & 10 & flat \\
\hline small & 40 & $\begin{array}{l}1.62 \times \\
1.22\end{array}$ & 1 & 4.5 & 1.5 & 1.5 & 8 & flat \\
\hline
\end{tabular}


Table 2 the distances from the screen to viewers; the left and right deflection angles; the elevation and depression angles

\begin{tabular}{|l|l|l|l|l|}
\hline & Extra-large & large & medium & small \\
\hline $\mathrm{r}_{\min }$ & $3.5 \mathrm{~m}$ & $4 \mathrm{~m}$ & $2 \mathrm{~m}$ & $1.5 \mathrm{~m}$ \\
\hline angle of depression & $15^{\circ} .19$ & $13^{\circ} .36$ & $12^{\circ} .68$ & $16^{\circ} .7$ \\
\hline angle of elevation & $30^{\circ} .36$ & $17^{\circ} .35$ & $27^{\circ} .7$ & $27^{\circ} .17$ \\
\hline Turn right & $63^{\circ} .43 \sim 72^{\circ} .35$ & $63^{\circ} .43 \sim 70^{\circ} .02$ & $66^{\circ} .04 \sim 72^{\circ} .9$ & $66^{\circ} .8 \sim 78^{\circ} .94$ \\
\hline Turn left & $40^{\circ} .60 \sim 63^{\circ} .43$ & $51^{\circ} .34 \sim 63^{\circ} .43$ & $36^{\circ} .87 \sim 60^{\circ} .26$ & $45^{\circ} \sim 64^{\circ} .32$ \\
\hline
\end{tabular}

The last row

\begin{tabular}{|l|l|l|l|l|}
\hline & Extra-large & large & medium & small \\
\hline $\mathrm{r}_{\max }$ & $20 \mathrm{~m}$ & $18 \mathrm{~m}$ & $10 \mathrm{~m}$ & $8 \mathrm{~m}$ \\
\hline angle of depression & $5^{\circ} .28$ & $5^{\circ} .40$ & $2^{\circ} .58$ & $3^{\circ} .22$ \\
\hline angle of elevation & $3^{\circ} .29$ & $10^{\circ} .59$ & $5^{\circ} .99$ & $5^{\circ} .5$ \\
\hline Turn right & $19^{\circ} .29 \sim 28^{\circ} .81$ & $23^{\circ} .96 \sim 31^{\circ} .43$ & $24^{\circ} .23 \sim 33^{\circ} .02$ & $23^{\circ} .63 \sim 32^{\circ} .62$ \\
\hline Turn left & $8^{\circ} .53 \sim 19^{\circ} .29$ & $15^{\circ} .52 \sim 23^{\circ} .96$ & $8^{\circ} .53 \sim 19^{\circ} .29$ & $10^{\circ} .62 \sim 21^{\circ} .3$ \\
\hline
\end{tabular}

From these tables, it is not difficult to find, students sitting left in the first row need to turn right up to nearly 80 degrees; students sitting right in the first row need to turn left up to nearly 65 degrees. The deflection angels are too large. Students sitting in the first row need to turn up to 30 degrees. When the author sits at the left seat of the first row, it is not very uncomfortable to watch the multimedia screen; that brings bad mood. But the number of these seats is relatively small. Sitting in the final row, the angles of deflection and elevation are very appropriate, but it is too far to reach the screen; sometimes the distance can be 20 meters, and the seat is not very good. Most seats provide appropriate distances, not very large angles to the left or right, and upward elevation angles in the appropriate range. The multimedia classrooms need to provide size, distance, left and right angles, elevation and depression angles which are consistent with following human eye movement laws. The horizontal movement of human eyes is faster than vertical movement; long time vertical movement is more easily to bring fatigue. The size and proportion on horizontal level are more accurate than those in vertical direction. In horizontal direction, the efficiency is high, and the error is small. Eyes are used to move from left to the right, from upper parts to lower parts. We see circles clockwise. The recognition of target in the best range of vision is rapid and accurate, and it is not easy to cause visual fatigue.

When using multimedia teaching technique, we need to consider all kinds of visual phenomena, especially the various visual differences caused by light intensity level, adaptation, the persistence of vision, different backgrounds, and different brightness. The normal visual range of the human is $46 \mathrm{CM} 71 \mathrm{CM}$, and the angle of view is $39 \sim 41$ degrees. The best sight distance is $50 \sim 55 \mathrm{CM}$, and the angle of view is no more than 40 degrees. The best height is the same level with eyes, while the upper and lower lines of sight should be within the range of $10 \sim 45$ degrees. The persistence of vision for human eyes is $1 / 16 \sim 1 / 10$ s, so the flash frequency cannot be too fast or too slow. The flash frequency is suitable for $0.67 \mathrm{HZ} 1.67 \mathrm{HZ}$, the transmission rate should be between $3 \sim 10 \mathrm{bit} / \mathrm{s}$. The comfort illumination for human is about 100LX. In addition, people's reflection on information enhances with the increase of information volume. After that, the efficiency reduces, while error rate increases. The sense of human brain is also influenced by educational environment. Therefore, in visual media design, multimedia teaching technique should be used combine with visual effects rules to achieve the best visual effects of multimedia teaching.

\section{The Hierarchical Structure of Multimedia Teaching Evaluation}

There are many factors affecting the effects of multimedia technology. The main factors are represented as following; the hierarchy structure is illustrated. 


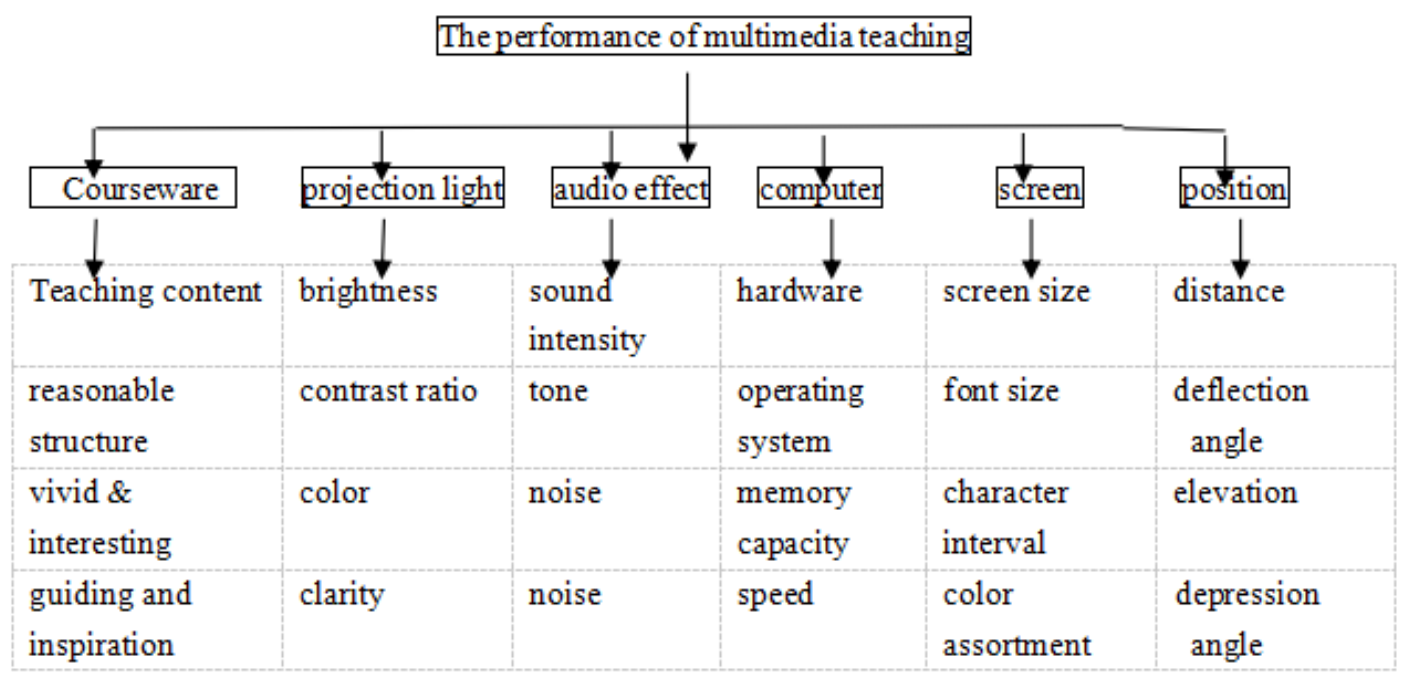

\section{Ordered Binary Comparison Method}

In the factor set, the importance of each factor is figured out after comparing one to another. According to multimedia teaching rules, the physical mechanism and characteristics of multimedia, as well as the psychological and physiological characteristics of students, the following relation table can be established.

\begin{tabular}{|l|l|l|l|l|l|l|l|}
\hline & screen & $\begin{array}{l}\text { projection } \\
\text { light }\end{array}$ & $\begin{array}{l}\text { audio } \\
\text { system }\end{array}$ & computer & courseware & position & M \\
\hline screen & 0.5 & 0 & 0 & 0 & 0 & 1 & 1.5 \\
\hline $\begin{array}{l}\text { projection } \\
\text { light }\end{array}$ & 1 & 0.5 & 1 & 0 & 0 & 1 & 3.5 \\
\hline audio system & 1 & 0 & 0.5 & 0 & 0 & 1 & 2.5 \\
\hline computer & 1 & 1 & 1 & 0.5 & 0 & 1 & 4.5 \\
\hline courseware & 1 & 1 & 1 & 1 & 0.5 & 1 & 5.5 \\
\hline position & 0 & 0 & 0 & 0 & 0 & 0.5 & 0.5 \\
\hline
\end{tabular}

When the number in the table of crossing is 1 , the importance of the factor in the correspondent row is greater than the importance of column. For example, the crossing of the second line, projection light and the third column, audio system is 1 , indicating that the lighting effect is stronger than audio system. Human beings obtain $83 \%$ information from watching, and $11 \%$ from hearing. When the number in the table of crossing is 0.5 , the importance of the factor in the correspondent row is equal with the importance of column. For example, the crossing of the first line, screen and the first column, screen is 1 , indicating that they have same effects. When the number in the table of crossing is 0 , the importance of correspondent row is smaller than the importance of column. For example, the number in the table of first line, screen and the third column, audio system is 0 , indicating that the effects of the screen is less than the effects of audio system. The rest may be deduced by analogy.

\section{The Relativity and Weight Coefficient of Each Factor}

\subsection{The relative weight table of 21 levels.}

According to the table, following data are obtained:

The relative weight of courseware is $\mathrm{Q} 11=1$, the relative weight of computer i $\mathrm{SQ} 12=0.905$, the relative weight of projection light is $\mathrm{Q} 23=0.905$, the relative weight of audio system is $\mathrm{Q} 34=0.667$, the relative weight of screen is Q45=0.143, and the relative weight of position is Q56=0.818.

The position is set as 0.818 , because the efficiency of information receiving relate to emotional feelings of the viewer. The psychological characteristics of human beings change according to the exponential law regardless of their satisfaction or boredom degrees. 


\begin{tabular}{|l|l|l|l|l|l|l|l|l|l|l|l|}
\hline $\begin{array}{l}\text { modal } \\
\text { adverb }\end{array}$ & $\begin{array}{l}\text { As } \\
\text { well }\end{array}$ & $\begin{array}{l}\text { A } \\
\text { littl } \\
\text { e }\end{array}$ & $\begin{array}{l}\text { sligh } \\
\text { tly }\end{array}$ & & $\begin{array}{l}\text { Relativ } \\
\text { ely }\end{array}$ & & $\begin{array}{l}\text { Obviou } \\
\text { sly }\end{array}$ & & $\begin{array}{l}\text { Significan } \\
\text { tly }\end{array}$ \\
\hline relative & 1.0 & $\begin{array}{l}0.9 \\
05\end{array}$ & $\begin{array}{l}0.8 \\
18\end{array}$ & $\begin{array}{l}0.73 \\
9\end{array}$ & $\begin{array}{l}0.66 \\
7\end{array}$ & 0.60 & 0.538 & 0.481 & 0.429 & 0.379 & 0.333 \\
\hline $\begin{array}{l}\text { modal } \\
\text { adverb }\end{array}$ & & $\begin{array}{l}\text { qui } \\
\text { etly }\end{array}$ & & $\begin{array}{l}\text { awfu } \\
\text { lly }\end{array}$ & & $\begin{array}{l}\text { Comple } \\
\text { tely }\end{array}$ & & $\begin{array}{l}\text { Extrem } \\
\text { ely }\end{array}$ & & $\begin{array}{l}\text { Unmatc } \\
\text { hed }\end{array}$ & \\
\hline relative & $\begin{array}{l}0.29 \\
0\end{array}$ & $\begin{array}{l}0.2 \\
5\end{array}$ & $\begin{array}{l}0.2 \\
12\end{array}$ & $\begin{array}{l}0.17 \\
6\end{array}$ & $\begin{array}{l}0.14 \\
3\end{array}$ & 0.111 & 0.081 & 0.053 & 0.026 & 0 & \\
weight & & & & & & & & & & & \\
\hline
\end{tabular}

\subsection{Ordered binary comparison.}

According to above table and ordered binary comparison method, that is formula of $\mathrm{P} 1 \mathrm{i}=\mathrm{P} 1 \mathrm{i}-1 \mathrm{Q} \mathrm{i}-1 \mathrm{i}$, of which 1 represents courseware, I = 2 6, represent computer, projection light, sound, screen and position respectively. P1i means the relative weight of other factors, Qi-1i means, set courseware as 1, use 21 level to calculate the weights of other factors. Q12, Q23, Q34, Q45, Q56 are $0.905,0.905,0.667 .0 .143$ and 0.818 respectively, their relative relations with courseware can be obtained.

$$
\begin{aligned}
& \mathrm{P}_{11}=1 \\
& \mathrm{P}_{12}=\mathrm{P}_{11} \mathrm{Q}_{12}=1 \times 0.905 \\
& \mathrm{P}_{13}=\mathrm{P}_{12} \mathrm{Q}_{23}=0.905 \times 0.905=0.819 \\
& \mathrm{P}_{14}=\mathrm{P}_{14} \mathrm{Q}_{34}=0.819 \times 0.667=0.546 \\
& \mathrm{P}_{15}=\mathrm{P}_{15} \mathrm{Q}_{45}=0.546 \times 0.143=0.078 \\
& \mathrm{P}_{16}=\mathrm{P}_{16} \mathrm{Q}_{56}=0.078 \times 0.818=0.064
\end{aligned}
$$

The courseware is 1 ; the relative relation between computer and courseware is 0.905 ; the relative relation between projector lighting and courseware is 0.819 ; the relative relation between audio system and courseware is 0.546; the relative relation between screen and courseware is 0.078; the relative relation between position and courseware is 0.064 .

\subsection{Weight coefficient.}

$$
\begin{aligned}
& \omega_{\mathrm{i}}=\frac{\mathrm{p}_{\mathrm{i}}}{\sum_{\mathrm{i}=1}^{6} \mathrm{p}_{\mathrm{i}}}, \\
& \sum_{\mathrm{i}=1}^{6} \mathrm{p}_{\mathrm{i}}=1+0.905+0.819+0.546+0.078+0.064=3.412
\end{aligned}
$$

After normalization process, the weights of courseware, computer, projection light, audio system, screen and position can be obtained as $\omega_{1} \frac{1}{3.412}=0.293, \omega_{2}=\frac{0.905}{3.412}=0.265, \omega_{3}=\frac{0.819}{3.412}=$

$$
\begin{aligned}
& 0.240, \quad \omega_{4}=\frac{0.546}{3.412}=0.160, \\
& \omega_{5}=\frac{0.078}{3.412}=0.023, \omega_{6}=\frac{0.064}{3.412}=0.019 。 \\
& \sum_{\mathrm{i}=1}^{6} \omega_{\mathrm{i}}=0.293+0.265+0.24+0.16+0.023+0.019=1
\end{aligned}
$$

\subsection{Comprehensive Evaluation Method}

The courseware gets $a_{1}$, computer gets $a_{2}$, projection light gets $a_{3}$, audio system gets $a_{4}$, screen gets $a_{5}$, positiongets $a_{6}$; the highest score is 100 .

$$
\mathrm{S}=\sum_{\mathrm{i}=1}^{6} \mathrm{a}_{\mathrm{i}} \omega_{\mathrm{i}}
$$

If S lies between 90 and 100, the rank is excellent; between 80 and 89, the rank is good, between 70 
and 79, the rank is medium; between 60 and 69, the rank is qualified; below 59, the rank is unqualified.

For example:

The performance of a multimedia lesson is evaluated as follows:

The courseware gets 95 points, the computer gets 90 points, the projection light gets 85 points, the sound effect gets 90 points, the screen effect gets 90 points, the position gets 85 points,

$\mathrm{S}=95 * 0.293+90 \times 0.265+85 \times 0.24+90 \times 0.16+90 \times 0.023+85 \times 0.019=90.17$

The result is excellent.

\section{Conclusions}

Based on ordered binary comparison and multi-level quantization method, a multimedia performance evaluation system is established in this paper. The method not only quantifies the results of qualitative analysis, but also concludes the subjective factors of people. Meanwhile, it analyzes various factors which influence multimedia teaching. This evaluation method is theoretically reliable and practical; it can also be used in the management and evaluation of other departments in modern education.

\section{References}

[1] G.B. Yang, Principles and Application of Fuzzy Mathematics, South China University of Technology Press, Guangzhou, 2011.

[2] F. Wang, The discussion of "power" and weight distribution method, J. Systems Engineering.11 (1993).

[3] L. Huang, Reflections on multimedia teaching, J. Journal of Huazhong University of Science and Technology. 03 (2004).

[4] L.P. Hong, Present situation and improvement measures of multimedia teaching in colleges and universities, J. Journal of Ningbo University. 4 (2003).

[5] L. Liu, Y.H. Sun, Exploration on the evaluation method of multimedia courseware in colleges and universities, J. Manufacturing Automation. 7 (2010). 